\title{
MECHANISM OF INFORMATION SUPPORT OF STATE MANAGEMENT OF ECONOMIC SECURITY OF UKRAINE
}

\author{
Liudmyla Akimova ${ }^{1}$ \\ ${ }^{I}$ Doctor of Science (Public Administration), Professor, National University of Water and Environmental \\ Engineering, Rivne, Ukraine, e-mail: l_akimova@ukr.net,ORCID: https://orcid.org/0000-0002-2747-2775
}

In Ukraine, as well as around the world, the problems of ensuring the economic security of the state, society and personality are increasingly coming to the fore in public policy and public administration. Information support of the state department of economic security is among the priority goals of the modern state and is one of the main factors of its stable development. Obviously, systemic defects and disruptions in the functioning of the mechanisms of information support of the state department of economic security can lead to socio-political, economic and man-made shifts that can undermine the possibility of public administration to properly carry out its main functions.

The purpose of the information support system is to provide its users with data that facilitates the adoption of informed and effective decisions by responsible public authorities and management within their competence, as well as the preparation of decisions of the superior instances, in compliance with a number of requirements and principles tested by the world and domestic experience of information technology. In the scientific literature, the concept of "information support" is most generally regarded as a set of in some way organized, controlled information recorded on the carriers of the system, as well as as the process of providing information. However, the most general understanding of information support as a process based on the system of informational ingredients: resources, technologies, technical means and information systems.

Information support of public authorities is a system of concepts, methods and means designed to provide users with information. Information here should be considered as some set of various messages, information, data on relevant subjects, phenomena, processes, relationships, etc. This information, being collected, systematized and converted into a usable form, plays an important role in the management. Public administration is essentially information management, where decisions are made on the basis of available documentary and information resources. The peculiarity of public administration in modern conditions is the need for comprehensive application of modern forms and methods of information and documentary support of the activities of public administration bodies. First of all, it is the use of the latest information technologies to support decision-making in order to ensure the effective functioning of the system. 
The system of information and analytical support of public administration can be defined as an interdependent and appropriately formed set of organizational, organizational, legal, informational, methodological, software and technological components, which provides the necessary quality of the adopted management decisions through the rational use of information resources and information technologies with a combination of the principles of problematic orientation and software-target installation both in relation to the topic of information support and regarding the selectivity of information preparation and bringing it to managers in accordance with their place in the management system and basic functional duties.

It should be noted that management structures as subjects of information support system constantly interact with the information environment, regulate the movement of information, analyze trends and develop recommendations for management decision-making. Therefore, the system of information support of public administration bodies should take into account the heterogeneity of the process of making managerial decisions and the specifics of the activities of officials of management structures of all categories at different stages of the decision-making process. At the same time, the specialist in information and analytical work faces a number of problems during his work.

From the point of view of "state-management analytics", the following processes define the essence of analytics are defined:

1) the process of analyzing management goals and forming tasks of information and analytical work;

2) the process of adaptive management of information collection to solve managerial problems in a changing situation;

3 ) the process of analyzing and evaluating the information received in the context of management goals, determining the essence of the processes and phenomena observed;

4) the process of building a model of the subject area of research, the object of research and wednesday its functioning, checking the adequacy of the model and its correction;

5) the process of planning and conducting model experiments;

6) the process of synthesis of new knowledge (interpretation of results, forecasting, etc.) that is necessary to solve management problems;

7) the process of bringing the results of analytical work (new knowledge) to the subject of management (structure or decision-making person) [1].

Consolidated information is public knowledge that is specifically selected, analyzed, prospered, evaluated, restructured and reserved for the purpose of fitness to directly address problems and meet the information needs of individuals or groups of users of information that would not have direct access to this knowledge in a different 
way and could not use them effectively because they are scattered across many documents and are difficult to access in their original form.

In recent years, public administration has seen a significant increase in the amount of information used and the flow of management documents, expansion of the entire record keeping. At the same time, the number of prepared documents and collected information is sometimes much greater than necessary for management processes. At the same time, there is a lack of information that should provide analysis of new trends and resolution of contradictions. In today's world, information is a strategic national resource that plays an increasing role. The authorities need to constantly collect a variety of information about the life of the regions in order to assess the needs and meet them both at the moment and in the future. At the same time, it is necessary to cover both actual problems and needs and potential. Information collection is a complex process based on both traditional and unconventional methods.

Almost all state structures provide information support for current work using personal computers with a set of typical software products. Most bodies use local computing networks. Possession of reliable and up-to-date information along with the ability to effectively use adequate methods of its collection, analysis and provision is the basis of successful activities of state bodies of any level.

The subject of public administration, producing management decisions, transfers them to the management facility, drawing up information in the form of organizational and regulatory documents (provisions, instructions, rules, orders, resolutions, decisions, etc.). Often, both oral and written interaction between the subject and the object is necessary to obtain an effective result in the management process, but for most management processes it is important to have information attached to the material carrier. Thus, the result of management depends on how thoughtful, systematically and professionally informational interaction between the subject and the management object takes place [2].

The purpose of the information provision is to obtain processed, generalized information on the basis of the collected initial data, which should become the basis for making management decisions. This goal is achieved by collecting primary information, storing it, distributing it among the structural subdivisions of the relevant services and their employees, preparing for processing, recycling its own, providing its governing body in a redesigned form, analyzing, providing direct and feedback in its circulation, organization of document flow, etc. The purpose of information support is to ensure that the decision-making person has the necessary and sufficient amount of information in the form of information units (messages, certificates, calculations, diagrams, diagrams, etc.) and the maximum possible 
options for solving the problem (proposals, advice or recommendations) with the assessment of the really predicted both positive and negative consequences.

An important tool for ensuring the openness of power is the media (media), which are an intermediary between the state and society and have a significant impact on the effectiveness of communication of the state-society. The quality of the functioning of the media largely depends on the real level of openness of power. It should be emphasized that ensuring information openness of state power is a bilateral process. On the one hand, there is the existence of a public request for objective and comprehensive information about the activities of the authorities, the active position of civil society towards the state authorities. On the other hand, the level of openness is determined by the real activities of specific public authorities.

- At present, the provision of information to citizens, according to the current legislation, is carried out through the press centers of state authorities through the periodic publication of press releases, notifications about the measures of public authorities, holding press conferences and briefings, establishing constant cooperation with the media, etc. In order to perform the basic functions, the information support system must take into account the heterogeneity of the management decision-making process and the specifics of the work of category officials at different stages of the management process. To do this, it must be directed to:

- development of methodological, software and information support tasks for monitoring the state of the object of state power and management;

- creation of a subsystem of information support for the activities of state authorities and management;

-supporting the control over the implementation of decisions and the effectiveness of executive mechanisms of public authorities and public administration; development of typical structures and methods of information support of management bodies;

- supporting the analysis of external and internal problematic situations and forecasting their development;

- research and development of methods and means of information support for the development of solutions in crisis and emergencies;

- formation of processes for preparing a meaningful part of management decisions and their documentary registration;

- assistance in analyzing the validity and legal legality of decision-making;

- facilitating coordinated procedures and collective decision-making processes;

- supporting the implementation of the functions of management of the activity of its own governing body [3]. 
The main direction of tasks inherent in public administration is documentation support of management. The solution of any of them involves a large amount of typical works, which include:

- processing of incoming and outgoing information: reading and replying to letters (both electronic and ordinary), writing reports, circulars and other documentation, which may also contain drawings and diagrams;

- collection and further analysis of some data, for example, reporting for certain periods of time by different departments or organizations that meets different selection criteria;

- preservation of the information received, ensuring quick access to it and searching for the necessary information at the moment.

In the state information space there are such sources that objectively generate managerial information:

- legislative and other acts that give the right of public bodies and civil servants to make certain managerial decisions or carry out managerial actions (decisions and actions on the implementation of laws and other regulations);

- citizens' appeal to state authorities to realize their legitimate interests and subjective rights (servicing and protecting the rights and freedoms of citizens);

- mandatory orders, instructions (directives) transferred on the managerial vertical from the superior state bodies to the lower standing ones to be implemented and which ensure the integrity of the public administration system;

- facts, relationships revealed in the processes of control (feedback), reflecting the state of the managed objects, as well as the level of functioning of the subject of management;

- crisis (extreme) and other difficult situations requiring prompt and active intervention of state bodies and officials (managerial information about the state of social processes). The existence of crisis sources determines the development of a priori necessary procedures (algorithms) of managerial actions [4].

Despite the uniqueness of the crisis situations, models of rapid response of specific government structures and officials should be thought out and worked out.

For the effective implementation of these tasks, the information support system must, first of all, function, that is, perform its direct functions. The range of functions of the information support system is determined by the current capabilities of information technologies and means of computer equipment. Within this potential of information technologies and means of computer equipment and with orientation to the needs of public authorities and management in the context of Euro-Atlantic integration processes, there is an objective need to create a system of information support for public authorities that would meet European standards.

The following standards may include: 
- maximum disclosure;

- the obligation to publish information about their activities by public authorities;

- promotion of the culture of open government;

- focus on the public interest in the edging of information;

- facilitating access to information; optimal cost of realization of the right to information;

- ensuring openness of work of state institutions; openness in legislative regulation [5].

Almost every public authority in the process of forming an internal information system faces a number of problems: duplication of collected information, its uneconoperable use, high level of cost of the system and costs of information sovereignty. This phenomenon is observed at the central and local levels of state power. One of the reasons for this is the finding of the state apparatus outside the center of the formation of information society.

This is due to the fact that neither the information that should work for the state apparatus, nor the documentary basis of management, nor the processes of document flow, the transition to a paperless system of information exchange are unordered. Against this background, the public sector is comparable to private, significantly different and lagging behind. At that time, in many countries there is an ordering of the structure of management of informatization processes and the issues of quality of management are solved.

Information support of the executive system is of particular importance for the formation of transparent processes of activity of the state apparatus. Today it is imperfect and is characterized by elements of parallel functions, inconsistency in the relationship between the apparatus of different branches of government, frequent structural reorganizations and personnel replacements. This determines the low level of development of the information and communication system of authorities and management. using various information arrays, both citizens and civil servants can not always get the right information and skillfully process it. One of the reasons for this is uncertainty, uncertainty and not regulation of the functional work of the state apparatus. Therefore, information technology and reference systems are not configured for a particular user. In this regard, current information technologies cannot be considered high-quality enough.

The quality of information support often depends on the system of manning information funds, organization of service system, qualifications, etc. These processes today are insufficiently coordinated, balanced and logical. To ensure these characteristics, clear planning for the development of organizational development of information technologies is required, which should be differentiated into different categories of users. The concept of quality is closely related to the category of 
efficiency. In particular, the effectiveness of the activities of public authorities and management largely depends on the quality of their information and analytical support.

It is advisable to note that information and analytical support is closely related to information and analytical work, which in public administration constitutes a set of actions in the interests of improving the effectiveness of management activities and aims to know the essence, causes, trends of developments and phenomena in information and analytical support of public administration of politics, consideration and evaluation of situations, development on the basis of analysis and processing of information conclusions, recommendations, comments. The final product of information and analytical work in public administration is an analytical document. It should be noted that in most countries information and analytical work is a developed sphere of business, which brings significant profits. Tracking market conditions, new products or services, strategies and plans of real and potential competitors is an indispensable attribute of the work of large private and public companies.

The main principles of information and analytical work in public administration are:

- formation of the purpose of research (this is the basis of the approach to solving the issue of "for what" research is carried out);

- creation of a notion apparatus (which allows forming judgments in certain categories); - ensuring sufficient awareness of the direct customer (management);

- disclosure of the meaning of facts;

- establishing causes and consequences;

- taking into account historical development and national character;

- determination of development trends;

- ensuring a high level of reliability;

- formation of conclusions and recommendations;

- the presence of feedback (the analyst should know the customer's assessment of how the results of research are used) [6].

Today, there is a paradoxical situation: on the one hand, the information space is filled with information resources somewhat super-large, and on the other hand - there is a lack of information in it, since the one that exists often does not meet the requirements of society. Because at the present stage we also observe such a phenomenon as information "pollution" of society. The processes of preparation and adoption of effective decisions on the preparation and implementation of the security measure become vital. At the same time, the quality of management decisions within the framework of management significantly depends on the depth of understanding of the situation and possible alternative approaches to solving numerous problems, among which there are still basic ones, such as: 
- internal political situation in Ukraine and in the region;

- state of internal stability of a particular region;

- international, international and state conflicts in which the country or region participates, or the likelihood of them being drawn into such conflicts;

- political climate, including terrorist activity, major political parties, their relations, popularity of politics conducted in the region;

- the degree of corruptness of local authorities;

- economic situation of the region and its impact on the political climate of the country as a whole [7].

Research, analysis and forecast of the functioning and development of such complex and poorly formalized systems, which are interrelated complexes of social, economic and socio-political spheres of life of regions, can not be carried out on the basis of intuitive perceptions of management bodies about the final result. All this leads to an increase in understanding of the significance of information and analytical activities. In this regard, appropriate analytical units are created, their organizational and methodological support is improved, the material and technical base is improved. Providing the decision-making person with an analytical product, which is not just an orderly set of individual fragments of the problematic industry, but a holistic picture that reflects the object of management in a convenient view, contains suggestions for options for alternative behavior and possible consequences, makes it possible to perceive the object in its dynamics.

The quality of information support largely depends on the functioning of not only such general objects as the state, society, people, but also any other object of smaller importance - a non-state legal entity, a citizen, etc. To improve the situation regarding the openness of public authorities, it is advisable to develop a comprehensive program of activity in the following areas:

1. Improvement of regulatory support. This direction should provide for the implementation of the following actions: clarification of the provisions of the legislation on the activities of public authorities in terms of determining informing citizens about the current activities of the state authority as an important task; a clear definition of the nature of the information obligatory for publication and the ways of its publication with the foreseen of appropriate funding.

2. Formation of sustainable internal beliefs in civil servants regarding their responsibility for informing the public about the activities of state power and acquiring the necessary knowledge and skills. An important means of this should be to make appropriate changes to the programs of training and retraining of civil servants.

3. Informing the population about his rights to access information about the functioning of public authorities, in particular through the involvement of NGOs in 
this activity, as well as justification and clarification of the reasons for making governmental decisions.

4. Implementation of modern forms of ensuring openness of power, such as public hearings, open expert discussions, etc.

5. Enhancing the legal and political culture of Ukrainian citizens.

6. The use of a set of concrete and effective measures to increase technological support of information openness (creation of a unified system of information and analytical support of state authorities and local self-government bodies.

7. Creation of effective mechanisms of control of both state and civic, especially with the help of the media, ensuring openness. 8. Formation of public demand for information about the activities of state power, the interest of citizens in obtaining it [8].

In addition, the main component of successful management is innovation. The technology of teams - flexible temporary creative groups focused on creating a new or improving old "product" should penetrate the practice of work of state institutions. "Command" management technologies should actively penetrate the practice of public service. They become the main tool for achieving individual commitment aimed at the main tasks. Management technology is the techniques, methods and order (consistency, regulations) of the management process as a whole and its components functions.

The information has a large both positive and negative potential of influencing the behavior of the subjects of the public administration system. It is the information processes that indicate the level of transparency of the functioning of the state apparatus. This is due to informing all subjects about the course of state policy, the state of the apparatus of power, the responsibility of employees, etc. The procedure for regulating the procedure for access of interested persons and organizations to materials on the activities of public authorities is also important.

On the basis of the above-mentioned research, the dissertation developed a mechanism of information support of the state department of economic security, which provides for the establishment of a relationship between the components of the economic security of the state, the subjects of state administration ensuring the economic security of the state, regulations and sources of information used to calculate the impact of public administration on ensuring the economic security of the state [9].

Implementation of the presented model is carried out sequentially. Thus, at the first stage, objects and subjects are installed, which carry out information support of public administration for each of the components of the economic security of the state, as well as subjects whose activities are subject to research for each of the components (Fig. 1 and Table. 1). Thus, the object of the mechanism of information 
support of the state department of economic security is information processes that reflect the state's policy on ensuring economic security. The subject is patterns of development of social information relations between the state and subjects of economic security.

Taking into account the multi-aspectiveness and importance of the functioning of economic security at different levels, it is necessary to identify the main subjects that ensure the economic security of the state (Fig. 1).

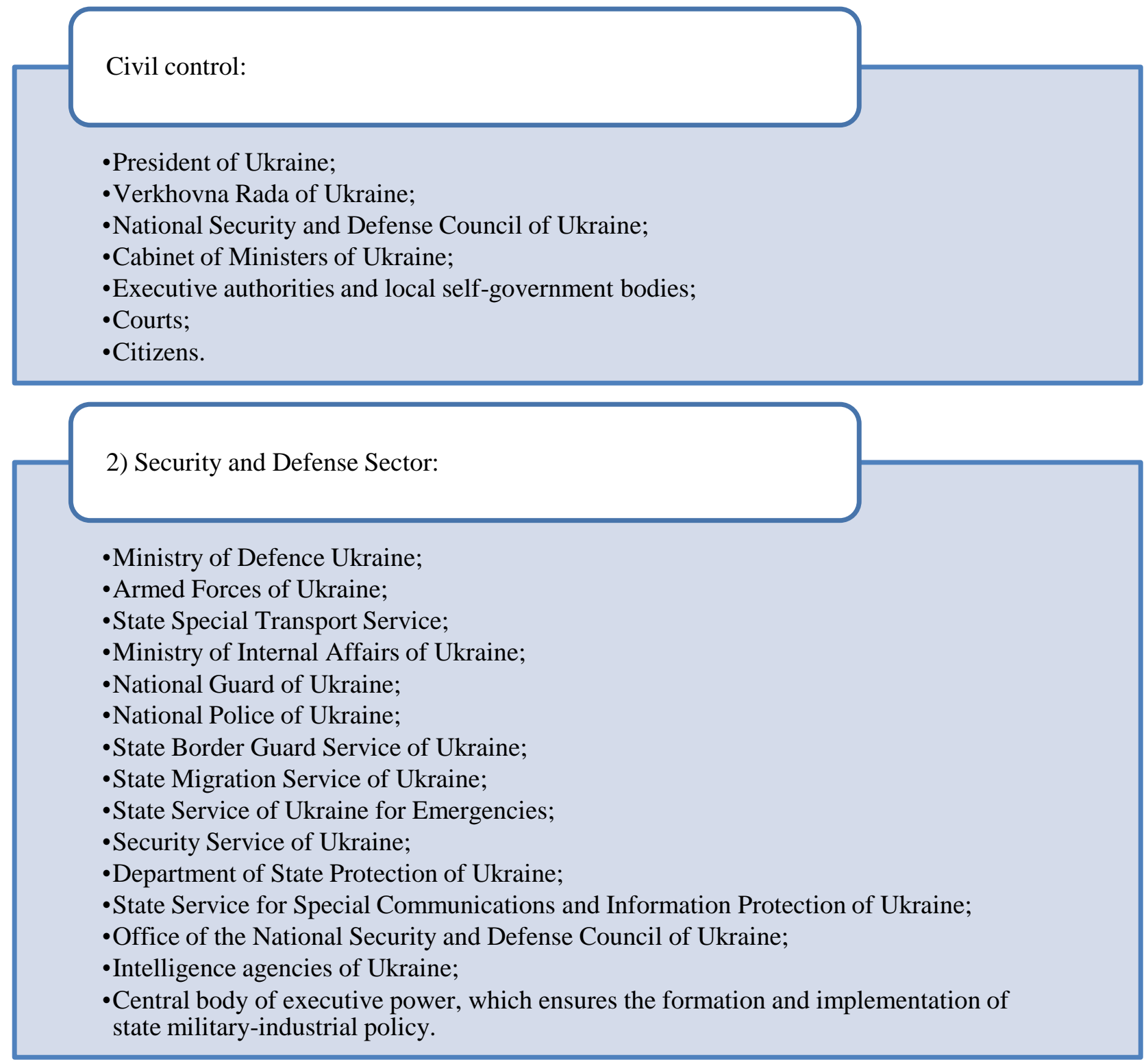

Fig. 1. The main subjects that ensure the economic security of the state Source: compiled by the author based on [10-24]

From fig. 1 we can conclude that the entities that ensure the economic security of the state are divided depending on their competence, that is, function in certain systems of civilian control and the security and defense sector. We propose to improve the relationship between the subjects of public administration to ensure the 
economic security of the state by systematizing them depending on the functions (planning, implementation, control); instruments of public administration (standard and electronic) and methods of ensuring economic security (Table 1).

Table 1. Relations between the subjects of public administration ensuring the economic security of the state

\begin{tabular}{|l|c|l|}
\hline \multicolumn{2}{|c|}{ Characteristic / Classification } & \multicolumn{1}{c|}{ Subjects } \\
\hline \multirow{2}{*}{ Depending on the functions } & planning & $\begin{array}{l}\text { Security Service of Ukraine, National Security } \\
\text { and Defense Council of Ukraine }\end{array}$ \\
\cline { 2 - 3 } & realization & $\begin{array}{l}\text { State Audit Office of Ukraine, Cabinet of } \\
\text { Ministers of Ukraine }\end{array}$ \\
\cline { 2 - 3 } $\begin{array}{l}\text { Depending on the institutions } \\
\text { of public administration }\end{array}$ & standard & $\begin{array}{l}\text { State Fiscal Service of Ukraine, National Bank of } \\
\text { Ukraine }\end{array}$ \\
\cline { 2 - 3 } & $\begin{array}{l}\text { Security Service of Ukraine, National Security } \\
\text { and Defense Council of Ukraine, State Audit } \\
\text { Office of Ukraine }\end{array}$ \\
\hline \multirow{2}{*}{$\begin{array}{l}\text { Depending on the methods of } \\
\text { economic security }\end{array}$} & prognostication & $\begin{array}{l}\text { The Verkhovna Rada of Ukraine, the Cabinet of } \\
\text { Ministers of Ukraine, the State Audit Office of } \\
\text { Ukraine }\end{array}$ \\
\cline { 2 - 3 } & $\begin{array}{l}\text { Security Service of Ukraine, National Security } \\
\text { and Defense Council of Ukraine }\end{array}$ \\
\hline
\end{tabular}

Source: compiled personally by the author

All of the above entities function in a certain legal field, while complying with the regulations presented in Fig. 2. that regulate the economic security of the state. At the second stage, the relationship between the subjects who carry out public administration for each of the components, as well as the subjects whose activities are subject to study (Fig. 2), and the normative legal acts regulating their activities is established. Reconciliation of these documents with each other will improve the accuracy of the assessment of the level of economic security.

At the third stage, the sources of information used to calculate the impact of public administration on ensuring the economic security of the state are established.

The proposed measures on public administration to ensure the economic security of the state will contribute to the strengthening of ukraine's national security in general and economic security in particular.

At present, Ukraine does not have a unified system of strategic forecasting and planning in the field of economic security, which would consider the security and defense sector as a holistic object of forecasting and planning. Implementation of a unified system of strategic forecasting and planning in the field of economic security in Ukraine will provide: timely and adequate response to real and potential threats to economic security, effective use of resources of security and defense sector bodies and forces, interrelation with other types of national planning and forecasting, 
correspondence between the priority of tasks in the field of economic security and the real amounts of their funding laid down in the draft State Budget of Ukraine , compliance of the documents of strategic planning of the state with the standards of the EU countries.

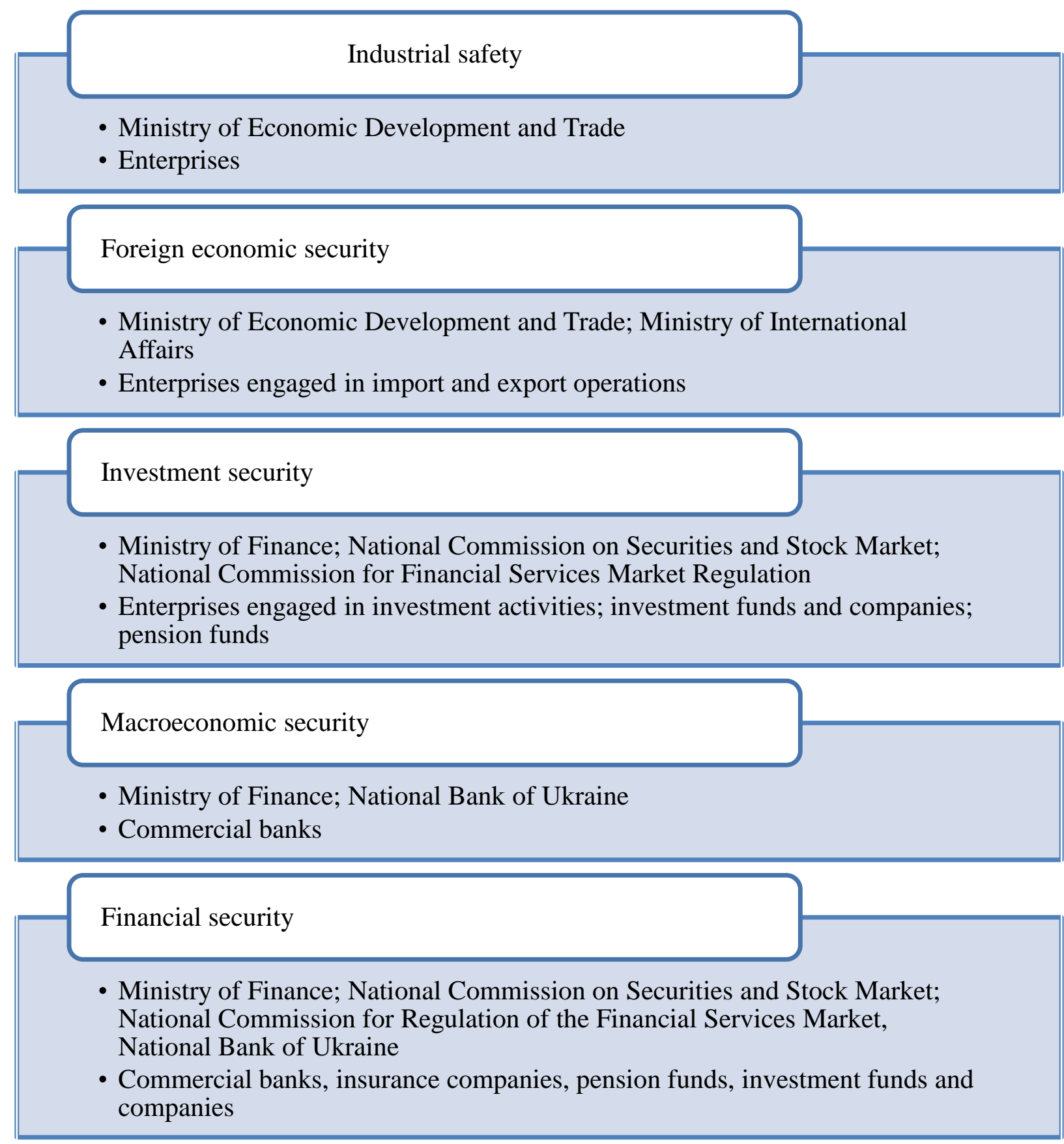

Fig. 2. The relationship between the components of economic security of Ukraine and the subjects who carry out public administration for each of the components, as well as the subjects whose activities are subject to research on

Source: compiled personally by the author

\section{each of the components}

In the course of the formation of a unified system of strategic forecasting and planning in the field of economic security and defense, it is necessary to ensure the 
relationship between the documents of long-term, medium-term and short-term strategic planning in the field of economic security and defense and their compliance with the national processes of strategic planning and preparation of the State Budget. At present, certain elements of the forecasting and planning system in the field of economic security are only at the stage of formation. This concerns, first of all, the formation of indicators (indicators) of the state of economic security and the creation of a unified system of monitoring, analysis, forecasting and decision-making in the field of economic security and defense.

We believe that the main directions of improvement of regulatory and legal support for economic security of the state should be: adoption of the law, in which the regulation and separation of the main aspects of economic security, in particular the definition of threats that adversely affect economic security, as well as steps to solve them; elimination of existing gaps in the regulatory framework; separation of powers of state regulation bodies.

\section{References:}

1. Akimova, L. M. (2020), "International experience of state management of economic security of the state in Ukraine", Aktualni problemy yevropeiskoi ta yevroatlantychnoi intehratsii Ukrainy [Current problems of European and Euro-Atlantic integration of Ukraine], materialy 17-yi rehionalnoi naukovo-praktychnoi konferentsii [materials of the 17th regional scientific-practical conference], DRIDU NADU, Dnipro, Ukraine, pp. 133-137.

2. Akimova, O. O. (2020), "Functional and competence component of public administration: content and sources of content", Derzhavne upravlinnia: udoskonalennia ta rozvytok, №1, retrieved from: http://www.dy.nayka.com.ua/?op=1\&z=1574. DOI: https://doi.org/10.32702/2307-2156-2020.1.29.

3. Akimova, L. M. (2019), "Public administration as a subject of ensuring the economic security of Ukraine", Investytsii: praktyka ta dosvid. Seriia: Derzhavne upravlinnia, №5, pp. 110-115.

4. Karpa, M. Akimov, O. and Shykerynets, V. (2020), "Implementation of innovative forms and models of public administration in the sphere of culture in Ukraine", Public Administration and Law Review, №3, pp. 13-23. DOI: https://doi.org/10.36690/2674-5208-2020-3-13.

5. Koval, Y. S. (2019), "Improvement of the information and analytical system of economic security of banks at the state level", Vcheni zapysky Universytetu «KROK», №2 (54), pp. 212-221. DOI: https://doi.org/10.31732/2663-2209-2019-53-212-221.

6. Mihus, I. Haman, P. Andriyenko, M. and Koval, Y. (2019), "The state of economic security of Ukrainian banking institutions and the effect of economic reforms on formation of anti-crisis measures", Financial credit activity: problems of theory and practice, №2(29), pp. 32-43. DOI: https://doi.org/10.18371/fcaptp.v2i29.171997.

7. Haman, P. and Haman N. (2019), "Implementation of the concept of enterprise management as a means of ensuring the efficiency of enterprise activities", Vcheni zapysky Universytetu «KROK», №1(53), pp. 105-109.

8. Parkhomenko-Kutsevil, O. I. (2020), "Information openness of the public governance system as the basis of national security", Naukovyi visnyk: derzhavne upravlinnia, № 5, retrieved from: https://nvdu.undicz.org.ua/index.php/nvdu/article/view/106/103.

9. Laptiev, S. and Mihus, I. (2018), "Threats to the economic security of Ukrainian issuers when placing shares on foreign markets", Yevropeiskyi naukovyi zhurnal Ekonomichnykh ta Finansovykh innovatsii, №2, pp. 39-47. DOI: https://doi.org/10.32750/2018-0205.

10.The official veb-site of President of Ukraine (2020), retrieved from: https://www.president.gov.ua/documents/all.

11.The official web-portal of the Verkhovna Rada of Ukraine (2020), retrieved from: https://rada.gov.ua/.

12.The official site of National Security and Defense Council of Ukraine (2020), retrieved from: http://www.rnbo.gov.ua/. 
13.The official site of Cabinet of Ministers of Ukraine (2020), retrieved from: https://www.kmu.gov.ua/ua/.

14.The official site of Ministry of Defense of Ukraine (2020), retrieved from: http://www.mil.gov.ua/.

15.The official site of State Special Transport Service (2020), retrieved from: https://www.ukrmilitary.com/p/state-special-transport-service.html.

16.The official site of State Ministry of Internal Affairs of Ukraine (2020), retrieved from: https://mvs.gov.ua/.

17.The official site of State Border Guard Service of Ukraine (2020), retrieved from: https://dpsu.gov.ua/.

18.The official site of State Migration Service of Ukraine (2020), retrieved from: https://dmsu.gov.ua/.

19.The official site of State Service of Ukraine for Emergencies (2020), retrieved from: https://www.dsns.gov.ua/.

20.The official site of Security Services of Ukraine (2020), retrieved from: https://ssu.gov.ua/.

21.The official site of Department of State Protection of Ukraine (2020), retrieved from: http://www.do.gov.ua/.

22.The official site of State Service for Special Communications and Information Protection of Ukraine (2020), retrieved from: http://www.dsszzi.gov.ua/dsszzi/control/uk/index.

23.The Verkhovna Rada of Ukraine (2018), The Law of Ukraine "About intelligence agencies of Ukraine", retrieved from : https://zakon.rada.gov.ua/laws/show/2331-14.

24.The official site of Judicial Chamber of Ukraine (2020), retrieved from: https://court.gov.ua/. 